Abstracta Iranica

Revue bibliographique pour le domaine irano-aryen

Volume 32-33 | 2013

Comptes rendus des publications de 2009-2010

\title{
Katja Lembke (éd.). Zypern - Insel der Aphrodite
}

Katalog zur Sonderausstellung, Roemer- und Pelizaeus-Museum Hildesheim

\section{Astrid Nunn}

\section{Q OpenEdition \\ 12 Journals}

\section{Édition électronique}

URL : http://journals.openedition.org/abstractairanica/40355

DOI : 10.4000/abstractairanica.40355

ISSN : 1961-960X

Éditeur :

CNRS (UMR 7528 Mondes iraniens et indiens), Éditions de l'IFRI

\section{Édition imprimée}

Date de publication : 1 décembre 2013

ISSN : 0240-8910

\section{Référence électronique}

Astrid Nunn, «Katja Lembke (éd.). Zypern - Insel der Aphrodite », Abstracta Iranica [En ligne], Volume 32-33 | 2013, document 93, mis en ligne le 01 juillet 2016, consulté le 28 septembre 2020. URL : http:// journals.openedition.org/abstractairanica/40355; DOI : https://doi.org/10.4000/abstractairanica. 40355

Ce document a été généré automatiquement le 28 septembre 2020.

Tous droits réservés 


\title{
Katja Lembke (éd.). Zypern - Insel der Aphrodite
}

\author{
Katalog zur Sonderausstellung, Roemer- und Pelizaeus-Museum
} Hildesheim

Astrid Nunn

\section{RÉFÉRENCE}

Katja Lembke (éd.). Zypern - Insel der Aphrodite. Katalog zur Sonderausstellung, Roemer- und Pelizaeus-Museum Hildesheim. Mainz, Philipp von Zabern Verlag, 2010. 280 p. 336

illustrations en couleur et 90 en noir et blanc.

1 Ce catalogue est, comme souvent les catalogues de grandes expositions, un résumé du savoir et de l'état de la recherche actuels concernant Chypre. Des spécialistes se sont penchés sur l'histoire de l'archéologie (S. Rogge), l'écriture et le trafic marchand (B. Rabe), les monnaies (A. Berthold), l'extraction de cuivre (H. Matthäus), les sanctuaires (A. Hermary) et Aphrodite (M. Hadjicosti) dans cette île. D'autres chapitres sont consacrés aux villes de Salamine (V. Karageorghis), Kition (S. Fourrier), Amathonte (A. Hermary, P. Flourentzos), Kourion et Paphos (B. Morstadt), Tamassos (H. Matthäus) et Marion (V. Lewandowski). Les chapitres étant organisés de manière diachronique, l'époque achéménide y est souvent évoquée et une cinquantaine d'objets exposés remontent à cette époque : céramique locale et importée, terres cuites, monnaies et statues chypriotes. Dans le dernier chapitre l'éditrice reprend le thème de son doctorat (cf. Abs. Ir. 27, 2004, c.r. $n^{\circ}$ 88) à savoir la sculpture chypriote trouvée à Amrit sur la côte syrienne. Ceci a pour conséquence que quatre statues des musées de Tartus et de Damas sont illustrées pour un grand public. 


\section{AUTEURS}

\section{ASTRID NUNN}

Université de Munich 